Monkevičienè, O., Vildžiūnienè, J., \& Valinčienė, G. (2020). The Impact of Teacher-Initiated Activities on Identifying and Verbalizing Ways of Metacognitive Monitoring and Control in Six-Year-Old Children.

\title{
The Impact of Teacher-Initiated Activities on Identifying and Verbalizing Ways of Metacognitive Monitoring and Control in Six-Year-Old Children
}

\author{
Ona Monkevičiené* \\ Vytautas Magnus University \\ Jelena Vildžiūnienè \\ Vytautas Magnus University \\ Galina Valinčienè \\ Vytautas Magnus University
}

*Corresponding Author: ona.monkeviciene@vdu.It
Received : 2019-08-20
Rev. Req : 2019-10-06
Accepted : 2019-11-30

DOI: $10.46303 /$ ressat.05.02.5

Monkevičienè, O., Vildžiūnienè, J., \& Valinčienè, G. (2020). The Impact of Teacher-Initiated Activities on Identifying and Verbalizing Ways of Metacognitive Monitoring and Control in Six-Year-Old Children. Research in Social Sciences and Technology, 5(2), $72-92$. doi.org/10.46303/ressat.05.02.5

\section{Abstract}

The qualitative research presented in this article attempts to show the impact of teacherinitiated activities on six-year-old children's metacognitive monitoring and control abilities. The metacognitive model is discussed, research findings that substantiate the development of separate components of metacognitive regulation are analyzed, and the educational ways that promote metacognitive development in children are systematized. The outcomes of the research show that teacher-initiated activities stimulate and encourage children to find and apply more diverse ways of metacognitive monitoring and control. After teacher-initiated activities, the target group children demonstrated, identified, and verbalized the following ways of acting and learning that had not been noticed in their self-initiated activities in the area of metacognitive monitoring, namely, thinking while doing, modelling, acting by scheme/without a scheme, and activity by self-created strategies. In the area of metacognitive control, the children showed the ability to challenge themselves to do better than before, think and do as a continuous, unbroken control and implementation process, and control performance consistency.

Keywords: preschool education, metacognition, monitoring, control. 
Monkevičienè, O., Vildžiūnienè, J., \& Valinčienè, G. (2020). The Impact of Teacher-Initiated Activities on Identifying and Verbalizing Ways of Metacognitive Monitoring and Control in Six-Year-Old Children.

\section{Introduction}

Metacognition and metacognitive regulation among preschoolers are nowadays the main focus of researchers and practicians. Research shows that the development of children's metacognitive regulating ways in the preschool years forms the background for learning to learn. Marulis, Palincsar, Berhenke, and Whitebread (2016) revealed that the components of metacognitive knowledge are very close to the skills needed for learning at school. Therefore, among children whose metacognitive knowledge is more comprehensive and who are able to apply their metacognitive skills in learning activities from three to five years of age, cognitive and metacognitive development is anticipated to be more advanced and their academic achievements higher. It has been established that metacognition stimulates self-regulated learning (Robson, 2010, 2016) and influences the child's choice of strategies for individual learning (Chatzipanteli, Grammatikopoulos, \& Gregoriadis, 2014). Metacognition has a certain effect on the quality of critical thinking (Magno, 2010) and on the relationship with better and more effective problem-solving skills (Lee, Teo, \& Bergin, 2009).

Metacognition is defined as children's "thinking about their own thinking" and metacognitive regulation as the ability to evaluate one's cognitive activities and act accordingly to achieve certain aims while doing a specific task or solving a problem (Vasile, 2010). Bernard, Proust, and Clément (2015) name two approaches to the metacognitive regulation of children. The first view claims that children's metacognitive regulation is possible only when they have a very clear understanding of the processes of their knowledge (perception, memory, reasoning, etc.) - that is when they develop concept-based metacognitive capacities. The other view is based on research showing that children have experience-based metacognitive knowledge (for example, they know what was harder or easier to do). According to the first view, metacognitive regulation is possible at around six years of age, whereas the second view claims that some forms of metacognitive regulation emerge much earlier.

A great deal of research has helped to reveal the development of the components of metacognitive regulation in children (Brinck \& Liljenfors, 2013; Brown, 1978; Lee et al., 2009; Whitebread, Bingham, Grau, Pino Pasternak, \& Sangster, 2007). The metacognitive regulation in four- to six-year-olds encompasses processes of planning, monitoring, control, and evaluation. According to Whitebread et al. (2009), Robson (2010, 2016), Rowe (2018), and others, any behavior or verbalization related to foreseeing a task and the choice of procedures for its implementation is considered planning. Monitoring refers to any behavior or verbalization related to a constant evaluation of the way a task is performed, observing one's own cognitive processes, ways of acting, and emerging problems. Control is any behavior or verbalization related to the change in the ways of acting with respect to monitoring results. Evaluation is any behavior or verbalization related to the performance of a task and assessment of the quality of its performance.

The analysis of the research shows that children's metacognition and metacognitive regulation have been investigated more in modelled experimental situations than in self-initiated 
Monkevičienè, O., Vildžiūnienè, J., \& Valinčienè, G. (2020). The Impact of Teacher-Initiated Activities on Identifying and Verbalizing Ways of Metacognitive Monitoring and Control in Six-Year-Old Children.

activities or everyday activities initiated by teachers (Bernard et al., 2015; Robson, 2010). The researchers have identified a variety of ways to stimulate the development of metacognitive regulation (Hyerle, 2014; Perry, Thauberger, \& Hutchinson, 2010; Roebers, 2017). However, stimulating the development of children's metacognitive regulation still remains a great challenge for teachers. Moreover, one of Robson's (2016) studies aimed at identifying the activity (a child's activity with an adult or with other children in the absence of an adult) more beneficial to the development of metacognitive skills yielded some unexpected results: A child engaging in activity without an adult's presence is much more useful for developing metacognitive regulation. Such results contradict the findings of other researchers. Therefore, it served as a precondition to the current research aiming to identify whether teacher-initiated activities assist children in applying more diverse metacognitive monitoring and control processes compared to self-initiated activities.

\section{Research Questions}

This study raises the following questions: Which metacognitive monitoring ways applied in both teacher-initiated and self- initiated activities are identified and verbalized by six-year-olds? Which metacognitive control ways applied in both teacher-initiated and self-initiated activities are identified and verbalized by six-year-olds? When do children identify and verbalize a wider qualitative variety of the applied ways of metacognitive monitoring and control-in teacherinitiated or self-initiated activities?

\section{Literature Review}

\section{The components of metacognition}

Metacognition is defined as a person's awareness of their own cognition and learning (metacognitive knowledge), and the use of that knowledge in regulating one's cognitive processes such as planning, monitoring, and control while learning, performing tasks, or solving problems (metacognitive regulation) (Brown, 1987; Flavell, 1979; Marulis, 2014; Marulis et al., 2016; Schneider, 2008). Flavell (1979) designed a model of cognitive monitoring that included metacognitive knowledge about one's own thinking and thinking of others, goal/task strategies, metacognitive experiences, cognitive and emotional thinking experiences (experiences related to thinking), cognitive goals/tasks, and cognitive strategies that help to reach cognitive goals. Brown (1987) extended the model by separating and distinguishing metacognitive knowledge from metacognitive regulation. Many researchers divide metacognitive knowledge into declarative knowledge, which is knowing about oneself and others as learners, knowing about one's own and others' cognition processes and learning; procedural knowledge, which is knowing about a goal/task, cognitive strategies, and how to employ them to achieve the goal/task; and conditional knowledge, which is knowing why, when, and how to use the strategies and how certain factors impact cognition (Lee et al., 2009; Vasile, 2010). The researchers claim that metacognitive knowledge is important for metacognitive regulation (Bernard et al., 2015; Lee et al., 2009). According to Lee et al. (2009), metacognitive regulation 


\begin{abstract}
Monkevičienè, O., Vildžiūnienè, J., \& Valinčienè, G. (2020). The Impact of Teacher-Initiated Activities on Identifying and Verbalizing Ways of Metacognitive Monitoring and Control in Six-Year-Old Children.
\end{abstract}

includes planning, monitoring, and evaluation, whereas, in the opinion of Whitebread et al. (2009) and Robson (2010), it includes planning, monitoring, control, and evaluation. Robson (2010), on the basis of the research into the connection among cognitive, social, and emotional aspects, also emphasizes emotional and motivational regulation, ways that are used to control emotional and motivational states while doing the task at hand. According to Brinck and Liljenfors (2013), metacognition needs to be related not only with the use of languages, symbols, and logical reasoning, but also with perceptual associations, emotions, motivation, and attention (especially while evaluating metacognitive expressions in children at a very early age).

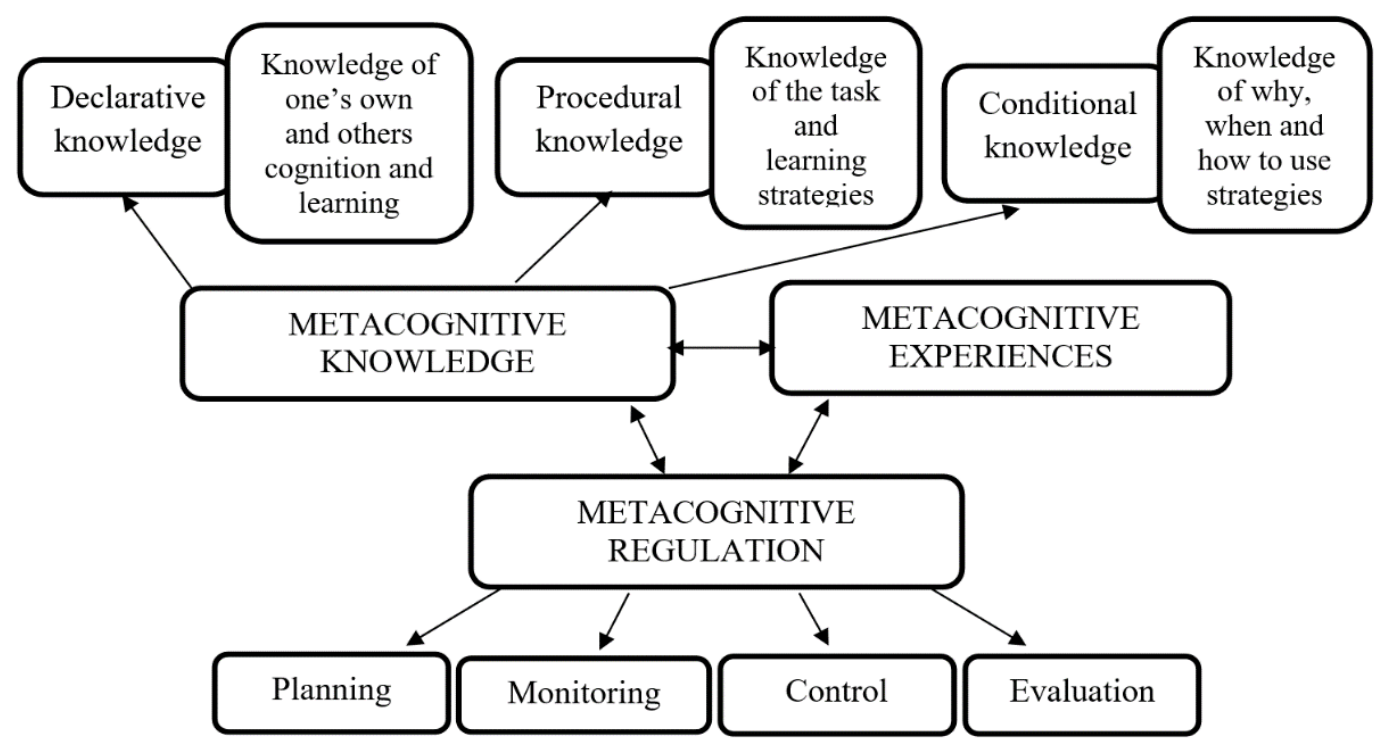

Figure 1. The components of metacognition (according to Flavell, 1979; Brown, 1987; Lee et al., 2009; Bryce \& Whitebread, 2012; Marulis, 2014; Robson, 2016).

Brinck and Liljenfors (2013) make theoretical assumptions that the most important metacognitive regulation processes are monitoring and control. Therefore, these two specific metacognitive components have been chosen to expand on the research.

\title{
Metacognition in early childhood
}

The research in metacognitive knowledge and metacognitive regulation in children shows that these two components are formed not sequentially but simultaneously, integrally. It has been proved by research that children who have not even reached one year of age already begin to develop a "theory of mind," since they begin to understand such mental phenomena as their own wishes and intentions (Wellman \& Liu, 2004). Lyons and Ghetti (2011) claim that two- to two-and-a-half-year-olds have certain initial metacognitive forms since they are able to evaluate what they know and what they do not know (metacognitive monitoring) and so they start using specific words in describing their states of mind, such as "to know," "to think," "I know," "I do not know." The research by DeLoache, Sugarman, and Brown (1985) shows that 18-month-old children spontaneously use the strategies for correcting mistakes. Thus, they 
Monkevičienè, O., Vildžiūnienè, J., \& Valinčienè, G. (2020). The Impact of Teacher-Initiated Activities on Identifying and Verbalizing Ways of Metacognitive Monitoring and Control in Six-Year-Old Children.

already have the initial forms of cognitive regulation, even though at this stage of their development the "theory of mind" is just forming. Brinck and Liljenfors (2013) theorize that the initial stage of metacognitive regulation is even earlier, at two to four months. Children at this age start participating in mutual monitoring and control interactions with an adult. Such monitoring and control involves implicit and perceptual metacognitive skills. This completely denies the attitude that metacognition is impossible in preverbal infants and the viewpoint that metacognitive regulation is possible only when children clearly understand their cognitive processes.

Bartsch and Estes (1996) substantiated the idea that three- to four-year-olds first learn to distinguish between cognitive and non-cognitive states, wishes, expectation, etc., and that knowledge forms the basis of metacognitive knowledge. Three- to five-year-olds gain a clearer understanding of their own and other people's minds and thinking. At this age, metacognitive knowledge in children consists of knowing about thinking and cognition, knowing about a task and strategies. Five- to seven-year-olds are already "experts" in the field of metacognitive knowledge (Lyons \& Ghetti, 2011). How children demonstrate their knowledge has been established (Marulis et al., 2016; Robson, 2016; Whitebread et al., 2009).

Less research has been done on the metacognitive regulation of children (on planning, monitoring, control, and evaluation). However, the research conducted so far shows that such skills are formed at quite an early age. It has been proved that two-year-olds monitor their own knowledge states (Brinck \& Liljenfors, 2013). Metacognitive monitoring strategies in children up to four years of age have not been differentiated (Feurer, Sassu, Cimeli, \& Roebers, 2015). Schraw and Moshman (1995) claim that four-year-olds are able to apply several strategies of learning regulation. The research results of Blöte, Resing, Mazer, and Van Noort (1999) show that the behavior of four-year-olds is strategical and that children at this age are able to develop and apply problem-solving strategies and transfer them to the new tasks.

On the other hand, it has been proved that children demonstrate well-developed metacognitive monitoring skills earlier than the control skills for the respective qualities. According to Destan, Hembacher, Ghetti, and Roebers (2014), although little children (up to five years of age) possess monitoring skills, they lack the skills to exploit information gained while monitoring to control their behavior. For example, five-year-olds distinguish very well between hard and easy tasks (which shows their monitoring skills) but do not allocate more time to the harder task (that is, making use of the knowledge), while six- to seven-year-olds give more time to the harder tasks after evaluating their complexity. Solution control is characteristic of children as young as five years of age. Children of this age group easily collected and placed in a "treasure box" the pictures they memorized well and threw away into a "garbage box" the pictures they did not memorize well. Thus, children demonstrated the ability to evaluate their decisions (Destan et al., 2014). The research of other authors supports the theory that five- to seven-year-olds (Bryce \& Whitebread, 2012) and in some cases even four- to five-year-olds (Robson, 2010, 2016) are already able to apply both monitoring and 
Monkevičienè, O., Vildžiūnienè, J., \& Valinčienè, G. (2020). The Impact of Teacher-Initiated Activities on Identifying and Verbalizing Ways of Metacognitive Monitoring and Control in Six-Year-Old Children.

control. At this age, these skills develop, qualitatively and quantitatively, rapidly. Six-year-olds successfully reflect on their own cognition (Schraw \& Moshman, 1995).

The analysis of other research shows that children of the chosen target group (six-year-olds) already possess metacognitive and monitoring skills. This finding provides reasonable assumptions by which to identify the impact of the teacher-initiated activity on the ways by which six- to seven-year-olds identify and verbalize metacognitive monitoring and control strategies.

\section{Educational ways applied to develop children's metacognition}

Researchers in education seek to systematize and substantiate ways that help the development of metacognitive knowledge and metacognitive regulation among children. These ways are classified into several groups, namely, developing metacognitive knowledge; directly modelling metacognitive regulation processes; creating challenging situations that naturally stimulate children's metacognitive reasoning and actions; creating an environment for joint child-play, communication, and learning; and joint participation of children and adults in learning activities.

The ways that develop children's metacognitive knowledge include a teacher talking to children clearly and in words that the children can understand about learning, thinking, and using the opportunity to reflect on one's own thinking (three- to seven-year-olds), and giving the children feedback. This helps the children to better perceive themselves as learners and to better understand their own knowledge and thinking (Chatzipanteli et al., 2014; Pramling, 1988).

The ways that directly model metacognitive regulation processes include the modelling of metacognitive skills (planning, monitoring, control, evaluation) through children's activities, encouraging children to use strategies such as imagination, focusing of attention and evaluation (Chatzipanteli et al., 2014); the use of thinking tools such as thinking maps; selfevaluation using visual criteria (Hyerle, 2014); exploration-based learning (White \& Frederiksen, 1998). This helps children to learn and apply the ways of metacognitive regulation in practice.

Challenging situations are created and metacognition is developed when children get involved in complex open-ended activities (Robson, 2010), when they are challenged to do what they have never done before, when there is a complex yet interesting and meaningful task that opens an opportunity to achieve several different goals and to act in different ways and in different directions - for example, to explore, create, evaluate, and re-create the lifecycle of a butterfly (Perry, Thauberger, \& Hutchinson, 2010; Roebers, 2017). According to the researchers, such tasks encourage children to choose solutions, think about themselves as learners, and think about the task itself and the strategies for its completion. The tasks also encourage the children to raise questions and predict outcomes. Children in such situations face difficulties, identify mistakes, choose among different ways of operation, and adapt them to a given situation (Roebers, 2017). 
Monkevičienè, O., Vildžiūnienè, J., \& Valinčienè, G. (2020). The Impact of Teacher-Initiated Activities on Identifying and Verbalizing Ways of Metacognitive Monitoring and Control in Six-Year-Old Children.

Creating an environment for joint child-play, communication, and learning. Chatzipanteli et al. (2014) emphasize the importance of joint play and group activities for children to encourage them to think aloud because it provides an opportunity for self-regulative talk and to start reflective dialogues and learn from each other.

Joint learning by children and adults happens when a teacher raises and addresses metacognitive, reflective questions for children to answer along with the teacher by applying specific ways of thinking together (Chatzipanteli et al., 2014). Marulis et al. (2016) noticed great progress in the field of metacognitive knowledge in four- to five-year-olds when children worked with teachers who created a process and favorable conditions to develop metacognitive knowledge that reflected on the children's educational activities and on the learning of the children.

\section{Methods}

This study aimed to discover the ways in which metacognitive monitoring and control were identified and verbalized by six-year-olds in self-initiated and teacher-initiated activities, and the impact teacher-initiated activities had on the identification and verbalization of the applied ways. The analysis of identification and verbalization of the metacognitive monitoring ways applied by the children encompassed the monitoring of self-cognition processes, monitoring of functioning and learning methods, and identification of failures, causes, and signs of problems. The analysis of identification and verbalization of the metacognitive control ways applied by the children involved conducting the control process itself, changing their own actions with respect to monitoring results as well as striving for a better outcome. The aspects of the analysis were determined considering the theoretical and empirical insights of Lee et al. (2009), Whitebread et al. (2009), Robson (2010, 2016), Marulis (2014), and Rowe (2018). Conclusions concerning the impact of teacher-initiated activities on children's identification and verbalization of metacognitive monitoring and control ways could be drawn due to the comparison of self-initiated and teacher-initiated activities, i.e., when children identify a wider qualitative variety of the applied ways of metacognitive monitoring and control.

\section{Research Design}

A qualitative research strategy based on constructivist theory was applied in the study (Berg \& Lune, 2012; Mayring, 2014). Such research enables disclosing unique experiences of participants and describing the surveyed phenomena and processes employing qualitative categories with reference to them. The object of the current research-identification and verbalization of metacognitive monitoring and control ways applied by children-is a phenomenon whose disclosure and description can be based on the unique subjective experiences of the children. 
Monkevičienè, O., Vildžiūnienè, J., \& Valinčienè, G. (2020). The Impact of Teacher-Initiated Activities on Identifying and Verbalizing Ways of Metacognitive Monitoring and Control in Six-Year-Old Children.

With reference to Destan et al. (2014), the process of metacognitive monitoring is usually assessed by asking the target group of individuals to explain or otherwise reveal their cognitive states before, during, and after the completion of a task. The process of metacognitive control is assessed by analyzing how the target group of individuals changes or adapts their behavior as they monitor the outcomes and seek to improve the results of their activities. According to Lee et al. (2009), researchers observe and record the language that children use-i.e., their reasoning about themselves as learners, about learning while doing the task at hand, and about their achievements. Researchers record verbal comments and/or use conversations, interviews, and questionnaires.

Following the above-mentioned methodological insights, the participants of the study were asked to perform a practical activity during which the application of metacognitive monitoring and control ways was inevitable. Then the researcher watched videos together with the participants, discussing the ways applied and raising reflective questions. Therefore, video material and records of reflective talks with children were used for data accumulation.

The qualitative content analysis technique, widely used by researchers for studying various texts, was employed for data analysis (Berg \& Lune, 2012; Mayring, 2014). The explorative design was also applied (Mayring, 2014; Saldana, 2016), in cases where categories were developed inductively from the text, as the surveyed phenomenon had not been substantially revealed and investigated. In the research, a phase as a category was distinguished when analyzing texts of the reflective talks with children with reference to their content and meanings, a phrase that characterized children's identified or verbalized ways of metacognitive monitoring or control. Texts of children's speeches were interpreted with reference to video material as a context enabling better understanding of the content and meaning of their ideas.

\section{Sampling}

Purposive sampling was applied in the study. The sample included six- to seven-year-olds attending preschool in the city (14 children) and rural areas (14 children). The choice of children's groups was random. The same 28 children participated in all four stages of the study.

\section{Research Procedure}

The study is performed in four stages with every child individually.

First stage. The researchers encouraged each child to draw or construct whatever the child wished, letting the child choose the idea and the means. The whole activity-the child's involvement, verbal comments, re-doings, completion of the work, etc. - was video-recorded by the researcher. During the research, although the children were encouraged to think aloud, there were no "think-alouds" because the children were so absorbed in their activities that they did not comment on the what, how, and why of whatever they were doing. Baker and Cerro (2000, p. 104) mention similar limitations: "Think-aloud procedures may disrupt the 
Monkevičienè, O., Vildžiūnienè, J., \& Valinčienè, G. (2020). The Impact of Teacher-Initiated Activities on Identifying and Verbalizing Ways of Metacognitive Monitoring and Control in Six-Year-Old Children.

processing of the task." That is why, based on Robson's (2010) research methodology, it was decided to include the second stage: a reflective talk with the child while watching the footage.

Second stage. Each child was shown the footage and asked some reflective questions: "What did you want to draw/construct?", "What did you want to learn?", "How did you decide what to draw/construct?", "How did you make a specific decision to draw/construct this particular thing?", "Did you think ahead of how to draw/construct it?", "What did you manage/fail to draw/construct the way you wanted?", "How exactly did you draw/construct it?", "What did you change or re-make?", "Which idea was the best one?", "Why?", "What did you learn while drawing/constructing or having drawn/constructed it?" The footage was shown to the children because they could hardly remember the process of their work without it. With the footage, the children were able to better remember and verbalize the ways of metacognitive monitoring and control they had applied.

Third stage. Each child was encouraged to draw or construct something suggested by their teacher. The child was provided a common idea for a drawing or craft, new ways or techniques of activity, and unexpected materials never used before. The teacher only initiated the child's activity but was not leading or managing the child in any way. Every child's activity was videorecorded with great emphasis on the signs of metacognitive regulation (as in Stage 1). Before the third stage, it had been presumed that an interesting and unexpected task being a challenge to a child would stimulate the appearance of metacognitive regulation. Such a presumption was based on the research of Perry et al. (2010), who claimed that tasks should be related to a child's opportunities to think metacognitively and behave strategically.

Fourth stage. The child was shown the footage and asked the same reflective questions as in the second stage.

\section{Findings}

\section{Metacognitive monitoring}

The metacognitive monitoring processes applied in both teacher-initiated and self-initiated activities were analyzed. The children's behavior and responses reveal that they perform the monitoring of their cognition processes, actions, failures, problem signs, and reasons.

\section{The monitoring of one's cognition processes}

The content analysis of the research revealed that during both the self-initiated and the teacher-initiated drawing and construction activities, the children identified and verbalized several aspects of the process of monitoring their cognitive processes. They demonstrated their empirical understanding of visual perception as a cognitive process. A boy constructed a watch according to his idea. Before choosing the color of the watchcase, he would take a part and put it on a yellow belt and would visually decide if they would fit together. The researcher 
Monkevičienè, O., Vildžiūnienè, J., \& Valinčienè, G. (2020). The Impact of Teacher-Initiated Activities on Identifying and Verbalizing Ways of Metacognitive Monitoring and Control in Six-Year-Old Children.

asked, "How did you decide that you needed to construct the watch this way?" The boy answered: "My brother once had one like that. I have seen it" (B:10, 6.8). The boy understood that one learns about things by looking at them. The children demonstrated their understanding of the thinking process and used the appropriate concepts. The researcher asked, "How did you decide what to do?" The boy answered, "I was thinking in my mind. The brain helps me" (B:10, 6.8). The boy understood that his mind is his thoughts and related thinking to the activities of the brain. He realized that thinking helps to create ideas for activities. The children noticed the connection between their thinking processes and the things they thought of and later implemented: "I came up with an idea of what to draw because I was thinking to draw the ocean. I managed to draw a bird, a sea-gull, and a dolphin" (G:4, 6.10). The child understood that one can implement the ideas that come to one's mind and saw the connection between the internal processes and actions in a real-life environment. The children noticed the connection between the focus of attention and the quality of the implemented goal: "I need to focus when I draw... that means I need to do it beautifully" $(G: 2,6.8)$. The girl realized that the focus of attention increases the quality of her activity.

In the teacher-initiated activities, the children identified and verbalized several new aspects of monitoring of cognitive processes. They noticed and verbalized their knowledge and the (in)congruity of their actions to their knowledge. Children were introduced to a new activity: stamping paints on a wet sheet of paper with little paper stamps made by them. A girl who stamped a butterfly later reflected, "I should not have messed with the water [should not have made the paper sheet wet]. Now everything looks kind of fluffy [commenting on how the paint spread in the water]. I knew that butterflies are fluffy on their neck only, not elsewhere" (G:18, 6.10). The children demonstrated an empirical understanding of tactile perception as a cognitive process. A girl was asked to construct a horse that she had never constructed before. Her horse bent over. The girl said, "When children run, they make wind. That is how the horse bent over" (G:25, 6.11). The child commented on a phenomenon that can be felt by touching. The children also demonstrated an empirical understanding of their aesthetical perception and creative work. A boy was asked to try a new technique: to blow paint through a straw. The researcher asked, "What did you want to create?" The boy: "The sea. I wanted to make some art. You know... when you make something beautiful" (B:17, 6.8).

The data show that teacher-initiated activities helped the children to monitor not only their thinking, visual perception and focus of attention but also their own knowledge and actions according to their knowledge, tactile and aesthetic perception, and the creative process.

\section{Monitoring one's ways of acting and learning}

After self-initiated activities, the children were able to identify and verbalize two ways of acting. They identified the way of acting with materials. The researcher asked, "How did you draw?" The boy answered, "I drew with a thick and thin [fiber-pen end]. It was most convenient to color using the thick end" (B:1, 6.2). They identified a way of learning by trial and error. The researcher asked, "How did you do it?" The boy answered, "I realized how to pick colors in a 
Monkevičienè, O., Vildžiūnienè, J., \& Valinčienè, G. (2020). The Impact of Teacher-Initiated Activities on Identifying and Verbalizing Ways of Metacognitive Monitoring and Control in Six-Year-Old Children.

more beautiful way. I realized that after building it for the third or fourth time" $(B: 12,6.11)$. These are just the most elementary ways of learning by doing.

After the teacher-initiated activities, the children identified and verbalized six new ways of acting and learning. They identified a way of thinking while doing. The teacher suggested to a girl that she draw an object using the grattage technique. The researcher asked, "How did you decide what you wanted to draw?" The girl answered, "I had no idea. But I realized that while drawing..." (G:21, 6.11). This particular case demonstrates that the girl monitors her inner process of thinking. The children identified a way of acting: modelling. A girl was suggested by the teacher to paint on paper with starch paste. When asked, the girl answered, "I wanted to paint some birds on that jelly. My teacher showed me... I saw outside" (G:16, 6.9). The girl realized that she was using the experience that she had gained in different ways. The children identified a way of learning: learning from an example, from another child. Regarding using the grattage technique, a girl said: "I looked at what you were doing and did it myself" (G:21, 6.11); regarding constructing an object from lines of different colors, another girl said, "I saw how Rytis did it" (G:24, 6.10). The first girl realized she had been learning from her teacher; the second girl realized she had learned from her classmate. The children identified a way of acting: copying. The children were encouraged to construct something they had never seen before with the constructor: "I had to copy the second wing so both could be identical" (G:28, 6.11). The child found an appropriate solution to make two identical objects. The children independently identified a way of acting, did not need instruction (scheme): "I can't really construct with this piece of paper. It was easier for me to build without paper" (G:28, 6.11). The comment shows that the girl not only identifies a way of acting with/without a scheme but also her ability to act in one way or the other. The children identified their activity strategies: to count, to measure, to compare. The suggestion to construct a horse that a girl had never constructed before was followed by her comment: "I was comparing the legs accordingly to the size. I counted the parts for the legs" (G:25, 6.11). There were many more reflections by the children, showing that children successfully apply all their acquired preschool skills as their own operational strategies and, importantly, identify them as their successful actions.

The data show that the teacher-initiated activities that seem like a challenge to children encourage and stimulate them to more actively monitor the ways of acting as well as the ways to identify and verbalize. During self-initiated activities, the children tend to use the usual ways of acting, in which their monitoring is not so obvious.

\section{Identification of failure and problem indications}

After self-initiated activities, the children were able to identify and verbalize a lot of signs of failures and problems. The children noticed and verbalized incongruity with the idea and goal: "I wanted to make a robot with arms and a sword. Arms are not double. The sword is not double. He cannot hold the sword" (B:13, 6.11). The children noticed and verbalized their mistakes by comparing the result with their imagining: "I made a mistake in the sky... I did not manage to paint clouds. They are kind of looking up" $(G: 4,6.10)$. This shows that during 
Monkevičienè, O., Vildžiūnienè, J., \& Valinčienè, G. (2020). The Impact of Teacher-Initiated Activities on Identifying and Verbalizing Ways of Metacognitive Monitoring and Control in Six-Year-Old Children.

monitoring, children compared the end result with what they had imagined. The children identified their success/failure according to their own schemes of drawing: "I managed! I have drawn it in kindergarten the same as it was at home" (G:5, 6.9). In this particular case, success/failure is identified by the degree of compliance of the action with own acting schemes. The children identified their success/failure according to the demands made by adults - the whole sheet of paper had to be filled: "I did everything well. I saw that my whole picture was filled" (B:1, 6.2). This shows that children decide about their success/failure by observing if their activity matches some external requirements. The children verbalized the inappropriate (in their opinion) characteristic features of their work - the size, forms, spaces, sustainability: "I could not draw a tail for this cat that's long enough at the first attempt" (G:6, 6.6); "Because it was round, not square" $(\mathrm{B}: 10,6.8)$; "The earth is not good enough because it is falling apart" $(G: 8,6.9)$. This proves that children base their decisions about successes and failures on the knowledge that they already have about the pictured objects. The children verbalized the aesthetic features of their works: "One wave did not seem nice" (G:7, 6.9). This observation indicates that children decide on their successes and failures according to an intuitive experience of beauty.

After the teacher-initiated activities, the children were able to identify two new signs of success/failure monitoring. The children verbalized the inaccuracies in joining different parts. A girl accepted the challenge proposed by her teacher to construct some object decorated with an ornament. She attempted to make a box with ornaments. She had to work very carefully and accurately. "I did not really fix the ends. Because it is difficult to make them firm. Because there are lots of small holes" (G:23, 6.11). The children noticed and verbalized new materials as a challenge. A girl attempted to make a flower from kinetic sand. "I did not manage to make its stem. It fell apart. I did not know how to make it from this kind of sand. You can build from it only the kind of fluffy buildings that soon fall apart" $(G: 19,6.6)$. The activity initiated by the teacher encouraged children to pay more attention to details and the fact that some unknown material qualities can determine the success or failure of the work.

The data show that six-year-olds have the well-developed ability to monitor their success and failure signs in self-initiated activities. The teacher-initiated activities encourage and stimulate them to give more attention to new materials and signs of new ways of acting relevant to the monitoring of success/failure.

\section{Identifying reasons for failures or problems}

A reflective talk with children shows that the monitoring of the reasons for a failure or a problem is much more complex for six-year-olds than the monitoring of the indications of a problem or a failure. After independent, self-initiated activities, children identified and verbalized only several reasons for their failures or problems. They identified and verbalized the lack of experience and personal skills: "I was not able to put all the toys in the shop. The shop I've drawn is too small" $(G: 2,6.8)$. The girl understood that she had arranged the objects in her drawing inappropriately. The children also identified and verbalized the result of the 
Monkevičienè, O., Vildžiūnienè, J., \& Valinčienè, G. (2020). The Impact of Teacher-Initiated Activities on Identifying and Verbalizing Ways of Metacognitive Monitoring and Control in Six-Year-Old Children.

previous activity as a hindrance to achieving further purposes: "I was not able to draw a market [it did not fit in the sheet]. The drawing was fully filled already" (B:1, 6.2). The child understands that his idea to draw a market came later after he had already drawn some cars, a house, and a road. All those things hindered him in accommodating the market in the picture. The children identified and verbalized the reasons for a problem such as lack of means/materials or their inapplicability to reach the goal: "The trees are not as I expected because there is no brown color" (B:3,6.6). The lack of means/materials or their inappropriateness/inapplicability was quite easy to detect as a reason for a problem.

The children were able to identify and verbalize more reasons for their failures and problems in the teacher-initiated activities. They identified and verbalized their inability to accurately foresee the result. Suggested by the teacher, a girl painted on a green sheet of paper covered in starch paste. "I painted the hair yellow... but you can't see my yellow on this green. So, I repainted it in black" (G:16, 6.9). The girl understood that her unusual activity with the materials she had never used before was the reason for not foreseeing a failure. The children identified and verbalized the reason for their failures-the unexplored characteristics of a new material: "I wanted to form some little balls and a dot but I could not make it because it [kinetic sand] was too fluffy" $(G: 19,6.6)$. The child tried to work with kinetic sand as if it was ordinary sand. Her failure intensified her metacognitive reasoning to identify the characteristics of kinetic sand as a possible reason for the failure. The children also noticed and verbalized the uncontrollable characteristic features of the usual materials as a possible reason for their failures. A boy was painting with watercolors. "I could not really make the other bird, a lark. The water has all blurred up" (B:15, 6.6). The child understands that you are meant to paint with watercolors, but you also need to have good skills to achieve a complex goal.

The comments of the children show that the monitoring of the reasons for possible failures or problems is a very complex process for six-year-olds. In self-initiated activities, the children were able to identify and verbalize only the lack of their own skills and the lack of appropriate/applicable materials as the reasons for their failures. The teacher-initiated activities encouraged and stimulated the children's metacognitive reasoning to view their unusual way of acting and unusual materials as additional factors that could affect the results and the quality of their work.

\section{Metacognitive control}

The metacognitive control processes applied in both teacher-initiated and self-initiated activities were analyzed. The children's behavior and speech disclose how they carry out the control of their activity and how they change ways of acting with respect to monitoring results.

\section{Identification and verbalization of the control process}

After self-initiated activities, the children identified and verbalized quite a number of control performance processes. They identified and verbalized the control of their activities focusing 
Monkevičienè, O., Vildžiūnienè, J., \& Valinčienè, G. (2020). The Impact of Teacher-Initiated Activities on Identifying and Verbalizing Ways of Metacognitive Monitoring and Control in Six-Year-Old Children.

on the goal. The researcher asked, "What did you want to draw?" The girl replied, "An ocean. I had to distinguish which animal to put into water and which to put in the sky. I had to try really hard..." (G:4, 6.10); "I've drawn it the way I thought" (G:5, 6.9). The children commented on their purposeful efforts to act according to the goal they imagined. They mentioned their efforts, performance strategies, and their ideas. The children identified and verbalized acting according to their plan: "First I chose my colors and later I constructed" $(G: 8,6.9)$. This shows that children already have some strategies in mind and are using them. They understand what strategies they use. Yet most often, children controlled their activities to attain the results of their desired quality for their work to look nice or not to fall apart, not to tear, not be able to bend or stand, or not fall, retain its given form, etc.: "I had to make this bird standing so I drew some toes on its feet" (G:11, 6.10); "That square had to be with little angles to not to fall apart" $(B: 14,6.10)$. The children had a clear vision of the result and the quality of that result. They controlled their acting in order to reach that result of the desired quality.

In the teacher-initiated activities, the children were able to identify and verbalize some new ways for their activity control. They verbalized their passion to meet the challenge to make things better than before: "I wanted this drawing to be better than the previous one. I had to learn" (G:18, 6.10). While trying stamping with paper stamps, the girl was controlling the quality of the process of her work, orientating it toward better results. The children commented on their thinking and doing as one integral and unbroken control process. "It's good to put some paint. To make the sea, too. I was thinking of where to put the paint and how to make it" (B:17, 6.8). The boy understood how he had controlled his performance-by thinking and doing. The children commented on the consistency of control of the action: "I did it the way you showed me. To draw with a candle, to strongly rub it in and then to draw with a crayon, paint with some paint and draw with a stick [grattage]" (G:21, 6.11). The girl controlled her action according to the consistent step-by-step instruction given by her teacher. The children commented on ways of control that helped them to work accurately: "I counted what I had [what was needed] in order to collect the green ones" (G:24, 6.10). The girl constructed a scarf by laying the lines of different colors and counting how many blocks she needed for that.

The children's comments show that during self-initiated activities, they take control of their activity to orientate it to work according to a specific plan and achieve the expected criteria of quality while attaining their goal. The teacher-initiated activity helped them see more ways of controlling activities, achieving better results, controlling thinking and acting as a continuous process, and controlling consistency and accuracy of activities.

\section{Performance change with respect to monitoring results and achieving a better result}

After self-initiated activities, the children identified and verbalized the ways in which they changed their activity. The children commented that after noticing the problem, they changed the way they acted: "As I opened the door, the land [the floor of the house] fell in. Then I took it all apart and rebuilt the floor on a table" $(G: 8,6.8)$. The girl at first constructed the floor of her house by joining the floor to the walls. Later, she first made the floor on the table and only 
Monkevičienè, O., Vildžiūnienè, J., \& Valinčienè, G. (2020). The Impact of Teacher-Initiated Activities on Identifying and Verbalizing Ways of Metacognitive Monitoring and Control in Six-Year-Old Children.

then started joining the walls to the floor. The children commented that, having noticed a problem, they already imagined a change and re-did the work according to their imagining: "Because in my imagination I saw something like this. There were too many light-colored blue clouds, so I painted one with dark blue" $(G: 6,6.6)$. The girl responded to the monitored results by using her imagination to find a solution. Having detected a problem and sought a specific result, the children commented on experimenting as a possible way: "I took off the legs at its head and fixed behind its [a hen's] tail. I had to construct it this way because the hen wanted to stand up straight. I needed to fix the legs behind its wings" (G:11, 6.10). Having detected a problem (that the hen was falling down, not able to stand straight), the girl experimented until she found how to balance the hen; only then did she fix the legs firmly. The children commented on the re-building (re-painting, re-doing) of their work: "The stick of the broom for my snowman was too short [thin], so later I made it bigger [thicker]" (B:5, 6.9). In this case, the child did not change the way of performance but only re-made the thing that failed. The children commented on constantly improving their skills: "I've managed to draw a rosebush and a kitten because I train a lot in drawing" (M:6, 6.6).

In the teacher-initiated activities, the children verbalized two previously unmentioned ways of considering the results of monitoring. They commented that, having noticed a problem, they looked at the book: "It is difficult to draw a peewit. It has a sort of tuft on its head. I looked at the book" $(B: 15,6.6)$. The children understood that the information that is found in books can help to solve problems. They also commented on choosing the right means/materials: "I blew the paint with this straw. It is longer, so much better because I can reach far with it" $(B: 17,6.8)$.

The outcomes of the research show that, for both types of tasks - self-initiated and teacherinitiated-six-year-olds adapt their actions to suit the situation, changing the ways of acting if needed, by using their imagination, experimenting, seeking information in books, or by remaking, correcting, changing the materials, etc.

\section{Results and Discussion}

The research has revealed that six-year-olds have some well-developed self-knowledge and performance monitoring skills. They not only demonstrate such skills in the self-initiated activities but are also able to identify and verbalize them. Six-year-olds successfully monitor the processes of their cognition (understanding, thinking, memory, attention), identify their own successes and failures, and detect the signs of a problem. However, they are less successful at identifying the reasons for their failures and problems. During self-initiated activities, they reason less metacognitively about the ways they perform and learn. Six-yearolds are able to use the information gained during the monitoring of the self-initiated activities to control their actions and behavior. Children exercise behavior control as they orientate toward a goal, seek to perform according to a plan, and meet certain quality criteria. Children adapt their performance to a specific situation by changing the ways of acting-using their imagination, experimenting, re-making, and correcting. Children are able to identify, verbalize, and apply metacognitive control ways. 
Monkevičienè, O., Vildžiūnienè, J., \& Valinčienè, G. (2020). The Impact of Teacher-Initiated Activities on Identifying and Verbalizing Ways of Metacognitive Monitoring and Control in Six-Year-Old Children.

The current research has expanded the indicators of children's metacognitive monitoring and control formulated by Whitebread et al. $(2007,2009)$. With reference to the research of the above-mentioned authors, three- to five-year-olds observe and verbalize their thinking and memory processes in their activity. The current study reveals that six-year-olds already carry out the monitoring of focusing their attention, visual and tactile perception, and even the monitoring of aesthetic perception. Six-year-olds can understand and verbalize the relationship between their cognitive processes and ideas of self-initiated activities, as well as the achievement of aims, between one's own knowing and acting with respect to knowing or not. Such aspects were not explored in the studies of Whitebread et al. $(2007,2009)$.

Whitebread et al. $(2007,2009)$ and Robson (2016) indicate that children select acting strategies, apply and change them, and notice mistakes and problems and eliminate them; however, particular strategies and problems identified by children have not been substantially described and systematized. Rowe (2018) also addresses the problem of such research limitations in his $\mathrm{PhD}$ thesis. The current study has an opportunity to analyze the situation from the perspective of six-year-olds, i.e., what acting strategies they select, what monitoring and control ways they apply, and what features and reasons they envisage for failures and problems, as well to systematize the findings.

According to Deston et al. (2014), children show good metacognitive monitoring skills before they learn good metacognitive control skills, which are quite weak up to five years of age. The current research has shown that six-year-olds (as observed in the target group) have good metacognitive monitoring and good metacognitive control skills.

The study aims to answer the following question: Do teacher-initiated activities stimulate sixyear-olds to apply a wider variety of ways of metacognitive monitoring, metacognitive control, and metacognitive reasoning related to those activities? In this regard, previous studies provide ambiguous conclusions. Whitebread et al. (2009) revealed that the participation of an adult assists children in demonstrating better metacognitive regulation abilities. The scholars conclude that adults foster frequent reflections of children that, in turn, contribute to the development of metacognitive regulation abilities. Robson (2016) revealed different results: four- to five-year-olds showed better self-regulation and metacognition when adults were absent, especially in areas of aim setting, progress monitoring, and conflict resolution. In the researcher's opinion, when an adult is present, children tend to delegate responsibility to the adult, hoping the adult will help them achieve their goals. The metacognitive aspect promoted by the presence of adults is procedural knowledge.

The current research has shown that the teacher has a stimulating effect on the development of metacognition. Judging from the results of the research, a teacher-initiated activity had significant impact on the children's ways of monitoring self-performance and learning. The children demonstrated, identified, and verbalized the following ways of monitoring: thinking 
Monkevičienè, O., Vildžiūnienè, J., \& Valinčienè, G. (2020). The Impact of Teacher-Initiated Activities on Identifying and Verbalizing Ways of Metacognitive Monitoring and Control in Six-Year-Old Children.

while doing, modelling, learning from an example or another child, acting by a scheme/without a scheme, performance strategies based on the acquired pre-academic skills.

In the area of metacognitive control, after a teacher-initiated activity, the children demonstrated, identified, and verbalized the following ways of performance control: rising to a challenge, seeking better results, seeking to do better than previously, seeing thinking and doing as one continuous control and implementation process, and the control of performance consistency. In the current research, unlike in the research conducted by Robson (2016), the teacher only initiated activities as a challenge but did not give any guidance, direct explanations, or help. Every child was encouraged to deal with the given challenge themselves. That may be the reason for the different outcomes from this study. An interesting finding is that six-yearolds understand thinking and doing as a continuous, unbroken process of control and implementation.

Researchers of the metacognitive regulation processes in children constantly explore the most efficient ways to enable children to disclose their metacognition. In the current research, such skills were demonstrated by the participants only after their activities had been recorded and the footage had been analyzed with them after the performance of the tasks and they were asked questions that induced reflection. The footage helped them to remember what they had experienced and how they had been thinking and acting. Without the footage, they would not have been able to recreate their performance process and subject it to metacognitive reasoning. Destan et al. (2014) consider that five- to seven-year-olds are hindered by memory limitations. According to Robson (2016), fewer cases of metacognitive regulation demonstration are recorded during a natural observation process in children, as children better demonstrate their metacognitive abilities not while playing or engaged in other activities but after the activity is carried out, when employing a reflective dialogue. Therefore, two causes limiting children's metacognitive expression are identified: (1) Children focus their attention on a single aspect of an activity, either carrying out the task itself or commenting on the activity; (2) A child's brain is not developed enough to allocate attention; due to memory limitations, children are unable to recall and comment on the whole process of carrying out an assignment without video material.

\section{Conclusion and Implications}

Teacher-initiated activities foster six-year-olds to apply, identify, and verbalize more ways of metacognitive monitoring and control of different quality than self-initiated children's activities. The impact is particularly explicit in the monitoring of one's acts and self-regulated learning, understanding self-control processes, and identifying reasons for problems and failures. Teacher-initiated activities are successful if modelled as challenges to children rather than as activities to be performed per clear instructions. In self-initiated activities, children are more likely to implement partially tested ideas. They employ a usual way of acting; therefore, their monitoring is not particularly obvious. Both self-initiated and teacher-initiated children's activities are favorable for identifying signs of problems and failures in children and changing 


\begin{abstract}
Monkevičienè, O., Vildžiūnienè, J., \& Valinčienè, G. (2020). The Impact of Teacher-Initiated Activities on Identifying and Verbalizing Ways of Metacognitive Monitoring and Control in Six-Year-Old Children.
\end{abstract}

the way they act with respect to monitoring results. Such metacognitive regulation experiences are gained through learning, experimenting, making mistakes, acting practically, and creating or recreating.

The children who participated in the study acted individually. Such performance could have influenced the application, identification, and verbalization of metacognitive monitoring and control processes. Rowe (2018) highlights that reflective dialogues among children playing together promote the development of metacognitive monitoring and control. Future research may focus on the impact of teacher-initiated activities on the metacognitive regulation of collaborating groups of children.

\title{
References
}

Baker, L., \& Cerro, L. C. (2000). Assessing metacognition in children and adults. In G. Schraw \& J. C. Impara (Eds.), Issues in the measurement of metacognition (pp. 99-146). Lincoln, NE: Buros Institute of Mental Measurements.

Bartsch, K., \& Estes, D. (1996). Individual differences in children's developing theory of mind and implications for metacognition. Learning and Individual Differences, 8(4), 281-304.

Berg, B. L., \& Lune, H. (2012). Qualitative research methods for the social sciences. Boston: Pearson.

Bernard, S., Proust, J., \& Clément, F. (2015). Procedural metacognition and false belief understanding in 3- to 5-year-old children. PLOS ONE, 10(10): e0141321. Doi:10.1371/journal.pone.0141321

Blöte, A. W., Resing, W. C. M., Mazer, P., \& Van Noort, D. A. (1999). Young children's organizational strategies on a same-different task: A microgenetic study and a training study. Journal of Experimental Child Psychology, 74, 21-43. Doi: 10.1006/jecp.1999.2508

Brinck, I., \& Liljenfors, R. (2013). The developmental origin of metacognition. Infant and Child Development, 22(1), 85-101. doi: 10.1002/icd.1749

Brown, A. (1987). Metacognition, executive control, self-regulation, and other mysterious mechanisms. In F. E. Weinert \& R. H. Kluwe (Eds.), Metacognition, motivation, and understanding (pp. 65-116). Hillsdale, NJ: Lawrence Erlbaum Associates.

Bryce, D., \& Whitebread, D. (2012). The development of metacognitive skills: Evidence from observational analysis of young children's behavior during problem-solving. Metacognition and Learning, 7(3), 197-217. 
Monkevičienè, O., Vildžiūnienè, J., \& Valinčienè, G. (2020). The Impact of Teacher-Initiated Activities on Identifying and Verbalizing Ways of Metacognitive Monitoring and Control in Six-Year-Old Children.

Chatzipanteli, A., Grammatikopoulos, V., \& Gregoriadis, A. (2014). Development and evaluation of metacognition in early childhood education. Early Child Development and Care, 184(8), 1223-1232. doi: 10.1080/03004430.2013.861456

DeLoache, J. S., Sugarman, S., \& Brown A. L. (1985). The development of error correction strategies in young children's manipulative play. Child Development, 56, 928-939.

Destan, N., Hembacher, E., Ghetti, S., \& Roebers, C. M. (2014). Early metacognitive abilities: The interplay of monitoring and control processes in 5- to 7-year-old children. Journal of Experimental Child Psychology, 126, 213-228.

Feurer, E., Sassu, R., Cimeli, P., Claudia M., \& Roebers, C. M. (2015). Development of metarepresentations: procedural metacognition and the relationship to theory of mind. Journal of Educational and Developmental Psychology, 5(1), 6-18.

Flavell, J. H. (1979). Metacognition and cognitive monitoring: A new area of cognitivedevelopmental inquiry. American Psychologist, 34(10), 906-911. doi:10.1037/0003066X.34.10.906

Hyerle, D. (2014). Catalyst. Pathways to thinking schools. USA: Corwin, a Sage Company.

Lee, C. B., Teo, T., \& Bergin, D. (2009). Children's use of metacognition in solving everyday problems: An initial study from an Asian context. The Australian Educational Researcher, 36(3), 89-102.

Lyons, K. E., \& Ghetti, S. (2011). The development of uncertainty monitoring in early childhood. Child Development, 82, 1778-1787.

Magno, C. (2010). The role of metacognitive skills in developing critical thinking. Metacognition and Learning, 5(2), 137-156. doi: 10.1007/s11409-010-9054-4

Marulis, L. M. (2014). Conceptualizing and assessing metacognitive development in young children. Dissertation, University of Michigan.

Marulis, L. M., Palincsar, A. S., Berhenke, A. L., \& Whitebread, D. (2016). Assessing metacognitive knowledge in 3-5-year-olds: The development of a metacognitive knowledge interview (McKI). Metacognition and Learning, 11(3), 339-368. doi: 10.1007/s11409-016-9157-7

Mayring, P. (2014). Qualitative content analysis: theoretical foundation, basic procedures and software solution. Austria, Klagenfurt. Retrieved from http://nbnresolving.de/urn:nbn:de:0168-ssoar-395173 


\begin{abstract}
Monkevičienè, O., Vildžiūnienè, J., \& Valinčienè, G. (2020). The Impact of Teacher-Initiated Activities on Identifying and Verbalizing Ways of Metacognitive Monitoring and Control in Six-Year-Old Children.
\end{abstract}

Perry, N. E., Thauberger, C., \& Hutchinson, L. (2010). Study traces of children's self-regulated learning in the lifecycles learning kit. Psychological Test and Assessment Modeling, 52(4), 432-453.

Pramling, I. (1988). Developing children's thinking about their own thinking. British Journal of Educational Psychology, 58, 266-278.

Robson, S. (2010). Self-regulation and metacognition in young children's self-initiated play and reflective dialogue. International Journal of Early Years Education, 18(3), 227-241.

Robson, S. (2016). Self-regulation and metacognition in young children: Does it matter if adults are present or not? British Educational Research Journal, 42(2), 185-206. doi: 10.1002/berj.3205

Roebers, C. M. (2017). Executive function and metacognition: Towards a unifying framework of cognitive self-regulation. Developmental Review, 45, 31-35.

Rowe, H. (2018). Very young children's reflections as indicators of metacognition. Durham theses, Durham University. http://etheses.dur.ac.uk/12636/

Saldana, J. (2016). The coding manual for qualitative researchers. Great Britain: SAGE.

Schneider, W. (2008). The development of metacognitive knowledge in children and adolescents: Major trends and implications for education. Mind, Brain, and Education, 2(3), 114-121. doi: 10.1111/j.1751-228X.2008.00041.x

Schraw, G., \& Moshman, D. (1995). Metacognitive theories. Educational Psychology Review, 7(4), 351-371. doi: 10.1007/BF02212307

Vasile, C. (2010). Developmental metacognition: Aspects in young children. Petroleum-Gas University of Ploiesti Bulletin, Educational Sciences Series, 62(2), 20-125.

Wellman, H. M., \& Liu, D. (2004). Scaling of theory-of-mind tasks. Child Development, 75(2), 523-541.

White, B. Y., \& Frederiksen, J. R. (1998). Inquiry, modeling, and metacognition: Making science accessible to all students. Cognition and Instruction, 16(1), 3-118. doi: 10.1207/s1532690xci1601_2

Whitebread, D., Bingham, S., Grau, V., Pasternak, D. P., \& Sangster C. (2007). The development of metacognition and self-regulated learning in young children: The role of collaborative and peer-assisted learning. Journal of Cognitive Education and Psychology, 6(3), 433-55. 
Monkevičienè, O., Vildžiūnienè, J., \& Valinčienè, G. (2020). The Impact of Teacher-Initiated Activities on Identifying and Verbalizing Ways of Metacognitive Monitoring and Control in Six-Year-Old Children.

Whitebread, D., Coltman, P., Pasternak, D. P., Sangster, C., Grau, V., Bingham, S., Almeqdad, Q., \& Demetriou, D. (2009). The development of two observational tools for assessing metacognition and self-regulated learning in young children. Metacognition and Learning, 4, 63-85. doi: 10.1007/s11409-008-9033-1 